\title{
ASS1 Gene
}

National Cancer Institute

\section{Source}

National Cancer Institute. ASS1 Gene. NCI Thesaurus. Code C118540.

This gene is involved in amino acid biosynthesis. 